\title{
New Kinds of Sapropel and Peat Based Fertilizers
}

\author{
Ludmila Agafonova ${ }^{1}$, Ina Alsina ${ }^{2}$, Guennadi Sokolov ${ }^{3}$, Svetlana Kovrik ${ }^{3}$, \\ Nikolay Bambalov ${ }^{3}$, Juris Apse ${ }^{4}$, Mikhail Rak ${ }^{5}$ \\ ${ }^{1}$ Latvia University of Agriculture (LLU), \\ Address: 2 Liela Street, Jelgava, LV-3001, Latvia \\ ${ }^{2}$ Latvia University of Agriculture at the Research Institute of Agriculture (LLU ZZI). \\ Address: Zemkopības institūts 7, Skrīveri, Skrīveru novads, Latvija, LV-5125 \\ ${ }^{3}$ National Academy of Sciences, Belarus. Institute for Nature Management (NAS INM) Address: \\ Skarina street 10, Minsk, 220114, Belarus \\ 4 "HuminVit" Ltd. \\ Address: Akmenu street 47, Ogre, LV-5001, Latvia \\ ${ }^{5}$ National Academy of sciences, Belarus. Institute for Soil Science and Agrochemistry (NAS ISSA), \\ Address: Kazinets street, 62, Minsk, 220108, Belarus
}

\begin{abstract}
New types of fertilizers based on peat and sapropel were developed and can be used as solid and liquid forms of organic and organicmineral fertilizers and preparations for different crop cultivation. It was shown that use of SAPROAgro and SAPROElixir fertilizers increases productivity of agricultural plants by 9-16\%. Use of EleGum liquid humic microelement fertilizers provides an increase of winter wheat grain yield up to $0.88 \mathrm{t} \mathrm{ha}^{-1}$, maize green mass up to $5.0 \mathrm{t} \mathrm{ha}^{-1}$ and maize grain to $2.06 \mathrm{t} \mathrm{ha}^{-1}$
\end{abstract}

Keywords: peat, sapropel, humic substances, macroelements and microelements, yield, agricultural plants.

\section{INTRODUCTION}

Many year experiences in a number of farms in Latvia and Belarus shows rather high efficiency of fertilizers application were obtained in result of peat and sapropel processing $[9,14,15]$. This is largely due to the favourable water-physical, agrochemical and biological properties, as well as a large variety in structure and composition of their organic matter.

As a high-quality organic-mineral fertilizer, sapropel can be used for many types of soils and plants, in order to increase the humus, nitrogen and microelements content in soil. It is classified as ecologically clean and efficient agricultural material of natural origin [2, 4]. Sapropel fertilizers, due to their high biological activity and preliminary technological treatment, resulted in the improvement of the structure of nitrogen-containing compounds in them and are able to make essentially better the quality of agricultural products as well [17].

Peat based organic fertilizers and preparations are even more widely used in agriculture in fact. Well known reason for that is a rich source of organic matter and biologically active substances [15]. Therefore, one of the most promising directions of peat use is its processing for obtaining such effective products as various biostimulants and plant growth regulators.

Microelements $\mathrm{Cu}, \mathrm{Zn}, \mathrm{B}, \mathrm{Mn}$, etc. participate in formation or activate action of enzymes, vitamins, regulate metabolism and many other processes effecting growth, development, reproduction, productivity and quality of plants [12]. They should be in a biologically available form in fertilizer and can be easily transformed and assimilated by plants. That is why the use of inorganic metal salts often is not efficient enough $[10,15]$. The best results are generally achieved when using liquid forms of preparations and fertilizers containing biologically active humic substances and microelements jointly [1, 17].

As far as balanced plant nutrition by necessary macro- and microelements plays most important role in crop cultivation technologies the new types of fertilizers based on peat and sapropel have been developed and studied $[8,9,13]$.

\section{MATERIALS AND METHODS}

To study of the efficiency of fertilizers based on sapropel, studies in LLU ZZI were conducted in 20122014. For this purpose, vegetation experiments were carried out in a climatic chamber, where conditions 
were simulated that are typical for a temperate climate, with such plants as alfalfa (Medicago sativa L.), mixture of cereal perennial grasses (Festuca rubra, 50\%, Festuca ovina, 50\%), tomato (Solanum lycopersicum) and lettuce (Lactuca sativa). Influence of SAPRO Agro and SAPRO Elexir on these plants different by physiological properties was tested. 1 litre plastic containers were used for experiments, filled with types of substrates: 1. Control - sand (SM) 2 . SAPRO Agro $\left(\mathrm{SA}_{100 \%}\right)$ 3. SAPRO Agro $\left(\mathrm{SA}_{1: 7}\right) 4$. SAPRO Agro-L $\left(\mathrm{SA}_{1: 7}+2 \mathrm{xSE}_{\mathrm{L}}\right)$ 5. SAPRO Agro-Ju $\left(\mathrm{SA}_{1: 7}+2 \mathrm{xSE}_{\mathrm{Ju}}\right)$. Plants were additionally fertilized (2x) with SAPRO Eleksir (SE) as a working solution 1:200 twice 5 and 12 days after shoots (variant 4 and 5). Experiments were carried out during 45 days.

SAPRO Elexsir fertilizer was tested in a field experiment in 2011-2013, where Rasa variety of barley (Hordeum vulgare L) was studied as one of the earliest and most responsive to fertilizers crop (LLU ZZI). Experiments were laid by method of randomized blocks, efficiency of additional fertilizing by SAPRO Elexsir was studied. Repeatability in experiments was 4x. Variantss: 1. Control - no additional fertilizing,2. Sapropel (SAPRO), 3. SAPRO Agro-L $\left(2 \mathrm{xSE}_{\mathrm{L}}\right), 4$. SAPRO Agro-Ju $\left(2 \mathrm{xSE}_{\mathrm{Ju}}\right)$. Additional fertilizing of plants was carried out by working solution of pure sapropel 1:20 (variant 2) and SAPRO Eleksir $\left(\mathrm{SE}_{\mathrm{L}}\right.$ and $\mathrm{SE}_{\mathrm{Ju}}$ ) as a working solution 1:200 (variant 2 and 3). Fertilizers were introduced by watering in tillering phase and 10 days after the first watering. Experiment plot soil in field experiment was slightly loamy sodpodzol and had a slightly acidic reaction $\mathrm{pH}_{\mathrm{KCL}} 5.7$. Content of humus $-20 \mathrm{~g} \mathrm{~kg}^{-1}, \mathrm{P}_{2} \mathrm{O}_{5^{-}} 90 \mathrm{mg} \mathrm{kg}^{-1}, \mathrm{~K}_{2} \mathrm{O}$ $125 \mathrm{mg} \mathrm{kg}^{-1}$.

Field experiments of Institute on Nature Management and Institute of Soil Sciences and Agrochemistry of National Academy of Sciences of Belarus were carried out in 2011-2013 with Cubus winter wheat variety on sandy-loam sod-podzol soil with $\mathrm{pH}_{\mathrm{KCL}} 6,5$. Humus content in soil was $30 \mathrm{~g} \mathrm{~kg}^{-1}$, $\mathrm{P}_{2} \mathrm{O}_{5}$ - $496 \mathrm{mg} \mathrm{kg}{ }^{-1}, \mathrm{~K}_{2} \mathrm{O}-203 \mathrm{mg} \mathrm{kg}{ }^{-1}$ [14]. The efficiency of liquid humic microelement EleGum fertilizers used for additional foliar treatment of plants was tested there.

Composition of liquid EleGum fertilizers based on preparation of humic acids (HA) as a biostimulant and complex former and microelements in helate form contained $10 \mathrm{~g} \mathrm{l}^{-1}$ of $\mathrm{HA}$ and respective mineral substances, e. g., EleGum-Cu contained $-50 \mathrm{~g} \mathrm{l}^{-1}$ of copper; EleGum-Zn - $50 \mathrm{~g} \mathrm{l}^{-1}$ of Zinc and EleGum$\mathrm{Mn}-50 \mathrm{~g} \mathrm{l}^{-1}$ of Manganese. These kind of fertilizers were developed by the Institute on Nature Management of National Academy of Sciences of Belarus [7, 8, 9].

Rate of fertilizer application was $11 \mathrm{ha}^{-1}\left(2001 \mathrm{ha}^{-1}\right.$ of working solution). The efficiency of humic microfertilizers was tested against the background of mineral fertilizers $\mathrm{N}_{150} \mathrm{P}_{70} \mathrm{~K}_{140}$ in variant for winter wheat and background of cow manure $50 \mathrm{t} \mathrm{ha}^{-1}$ and $\mathrm{N}_{180} \mathrm{P}_{90} \mathrm{~K}_{180}$ - in variant for Maize (Hybrid Dolphin). Experiments were laid by method of randomized blocks [3] and the repeatability in experiments as $4 \mathrm{x}$. Versions: Winter wheat: 1. Background, 2. Humic preparation, 3. EleGum-Cu, 4. EleGum-Mn, 5. EleGum-Cu + EleGum-Mn; Maize: 1. Manure, 2. EleGum-Zn, 3. EleGum-Cu, 4. EleGum-Mn.

Studies, measurements and determination of dry matter, chemical and biochemical analyses according to generally accepted methods described by national and industry standards (US EPA, LVS ISO, LVS EN, STANDART). Content of amino acids (except tryptophan) was studied by method of hydrolysis (AOAS Official Method 985.28.). Tryptophan - by spectrophotometric method at oxidation of the sample $\left(\mathrm{H}_{2} \mathrm{SO}_{4}\right.$ and $\left.\mathrm{HNO}_{3}\right)$ [5]. Morphologic factors of plants were also determined [3].

\section{RESULTS AND DISCUSSION}

\section{Content of nutrients in sapropel* and studied fertilizers}

Three components can be allocated in sapropel that interact with each other: biologically active, organic and mineral.

TABLE I.

COMPONENT COMPOSITION OF SAPROPEL

\begin{tabular}{ll}
\hline Parameter & Mean \pm SD \\
\hline Organic Matter, $\%$ & $77.3 \pm 4.90$ \\
Humic Acids, \% & $20.70 \pm 2.22$ \\
Fulvic Acids, \% & $32.70 \pm 3.15$ \\
Fatty acids $\omega-6 / \omega-3, \mathrm{~g} \mathrm{~kg}^{-1}$, & $14.40 \pm 2.2$ \\
Carbohydrates, $\mathrm{g} \mathrm{kg}^{-1}$, & $6.00 \pm 0.5$ \\
Lipids, \% & $12.25 \pm 1.40$ \\
Cellulose, \% & $22.42 \pm 1.80$ \\
Vitamins, mg kg- & \\
A (retinol) & $26.51 \pm 1.82$ \\
$\mathrm{~B}_{1}$ (thyamine) & $1.45 \pm 0.02$ \\
$\mathrm{~B}_{2}$ (ribiflavin) & $2.35 \pm 0.08$ \\
$\mathrm{~B}_{3}$ (PP.nicotinic acid) & $59.78 \pm 4.16$ \\
$\mathrm{~B}_{6}$ (pyridoxine) & $0.72 \pm 0.01$ \\
$\mathrm{~B}_{12}$ (cyancobalamin) & $0.03 \pm 0.00$ \\
Provitamin for vitamin $A$ ( $\beta$-carotene) $2.20 \pm 0.13$ \\
E ( $\alpha$-tocopherol) & $25.42 \pm 1.35$ \\
N(ascorbic acid+ dehydroaskorbic & $490.00 \pm 23.00$ \\
acid) & \\
\hline
\end{tabular}

Organic matter of sapropel is the aggregate of plant and animal residues and their decay products. It contains products of biopolymer hydrolysis, polymeric compounds formed in the process of biotic and abiotic destruction, products of organic synthesis, as well as waste products of microorganisms - vitamins and other biologically active substances. 
Component composition of sapropel is shown in Table I. Amount of fulvic acids improving availability of nutrients to plants was $32.70 \%$, which is by $12 \%$ higher than content of humic acids.

Total amount of carbohydrates $-6.00 \mathrm{~g} \mathrm{~kg}^{-1}$, include monosaccharides, disaccharides, oligosaccharides and polysaccharides, which is useful for plants: both for winter hardiness and resistance to other adverse weather conditions.

Composition has valuable $\mathrm{B}_{1-12}$ group vitamins, as well as vitamin $\mathrm{C}$ and carotenoids, they not only provide for nutrition of plants, but also favourably affect development of microflora and increase biological activity of the environment. Fats make $12.25 \%$ of dry matter and mainly are polyunsaturated fatty acids $\omega-3$ и $\omega-6$, participating in restoration of telomeres in DNA cell molecules and preventing aging of the organism [11]., which favourably affects development of plants during the vegetation period.

Amount of amino acids in sapropel was $11.93 \%$ (Table II). When using sapropel as a component of organic fertilizers, they are not only a physiologically active binder of the base having high ion exchange and sorption properties [10], but also an additional supplier of humic substances, amino acids, including aspartic $(1.41 \%)$, glutamic $(1.47 \%)$, as well as glycine $(0.79 \%)$, alanine $(0.85 \%)$ and leucine $(1.08 \%)$, into nutrient medium of plants.

TABLE II.

AMINOACID COMPOSITION OF SAPROPEL

\begin{tabular}{ll}
\hline Amino acids & Mean $\pm \mathrm{SD}$ \\
\hline Glycine & $0,79 \pm 0.08$ \\
Alanine & $0.85 \pm 0.08$ \\
Valine & $0.16 \pm 0.02$ \\
Leucine & $1.08 \pm 0.10$ \\
Isoleucine & $0.17 \pm 0.01$ \\
Methionine & $0.03 \pm 0.01$ \\
Tryptophan & $1,06 \pm 0.01$ \\
Proline & $0.31 \pm 0.03$ \\
Serine & $0,68 \pm 0.07$ \\
Threonine & $0.59 \pm 0.06$ \\
Aspartic acid & $1.41 \pm 0.13$ \\
Glutamic acid & $1.47 \pm 0.14$ \\
Lysine & $0.49 \pm 0.04$ \\
Arginine & $0.40 \pm 0.04$ \\
Histidine & $0.71 \pm 0.07$ \\
Phenylalanine & $0.29 \pm 0.02$ \\
Tyrosine & $1,44 \pm 0.14$ \\
Sum & $11.93 \pm 0.18$ \\
\hline
\end{tabular}

Mineral complex includes main macro elements as nitrogen, phosphorus, potassium as well as considerable amount of microelements $\mathrm{Mn}, \mathrm{Cu}, \mathrm{Zn}$, etc. (Table III). Anions of mineral substance of sapropel are mainly represented by carbonates, phosphates, sulphates. Components of mineral substance of sapropel participate in biologic processes, are transformed in redox reactions into substances easily available to plants.

TABLE III.

MINERAL COMPLEX OF SAPROPEL

\begin{tabular}{ll}
\hline Macroelements & Mean $\pm \mathrm{SD}$ \\
\hline $\mathrm{N}$ tot $\%$ & $2.80 \pm 0.30$ \\
$\mathrm{P}_{2} \mathrm{O}_{5}, \%$ & $0.15 \pm 0.02$ \\
$\mathrm{~K}_{2} \mathrm{O}, \%$ & $0.22 \pm 0.01$ \\
$\mathrm{CaO}, \%$ & $0.70 \pm 0.01$ \\
$\mathrm{MgO} \%$ & $0.17 \pm 0.00$ \\
\hline Microelements & Mean $\pm \mathrm{SD}$ \\
\hline $\mathrm{S}, \mathrm{mg} \mathrm{kg}^{-1}$ & $1.06 \pm 0.80$ \\
$\mathrm{Fe}, \mathrm{mg} \mathrm{kg}^{-1}$ & $7745.00 \pm 775$ \\
$\mathrm{~B}, \mathrm{mg} \mathrm{kg}^{-1}$ & $0.85 \pm 1.38$ \\
$\mathrm{Mo}, \mathrm{mg} \mathrm{kg}^{-1}$ & $0.43 \pm 0.03$ \\
$\mathrm{Cu}, \mathrm{mg} \mathrm{kg}^{-1}$ & $13.00 \pm 1.45$ \\
$\mathrm{Mn}, \mathrm{mg} \mathrm{kg}^{-1}$ & $32.00 \pm 3.40$ \\
$\mathrm{Zn}, \mathrm{mg} \mathrm{kg}^{-1}$ & $70.00 \pm 4.10$ \\
\hline
\end{tabular}

This has an important practical meaning when using sapropel as a fertilizer. Amino acidic composition, increased level of linolenic acid $\omega-3$, optimal content of minerals allows using sapropel not only in plant cultivation, but also in medicine and zootechny [1, 12].

In result of studies, agrochemical supplements were developed (LLU ZZI) for colloidal SAPRO Elixir fertilizer based on dispersed sapropel (100\%) and for SAPRO Agro fertilizer in form of nutritional substrate (sapropel $55 \%$; peat $45 \%$ ).

As a nutritional substrate, SAPRO Agro (SA) contained $86.8 \%$ of organic matter, $\mathrm{pH}-5.3$. Fertilizer dry matter had macroelements necessary for plants: $\mathrm{N}_{\text {tot }}-0.41 \% ; \mathrm{P}_{2} \mathrm{O}_{5}-0.28 \% ; \mathrm{K}_{2} \mathrm{O}-0.30 \%$, and $\mathrm{Mg}$ $-0.17 \%, \mathrm{CaO}-0.7 \%$, as well as microelements $(1 \mathrm{~m}$ $\mathrm{HCl}): \mathrm{Mn}-60 \mathrm{mg} \mathrm{l}^{-1} ; \mathrm{Cu}-11 \mathrm{mg} \mathrm{l}^{-1}, \mathrm{Zn}-9 \mathrm{mg} \mathrm{l}^{-1}$; $\mathrm{Fe}-2150 \mathrm{mg} \mathrm{l}^{-1}$; Mo $-0.43 \mathrm{mg} \mathrm{l}^{-1}$; $\mathrm{B}-4 \mathrm{mg} \mathrm{l}^{-1}$. This is an average level of nutrients sufficient for early growth and development of plants.

Composition of liquid colloidal fertilizers was: 1 . SAPRO Elixir ${ }_{\mathrm{L}}\left(\mathrm{SE}_{\mathrm{L}}\right): \mathrm{N}_{\text {tot }}-9.11 \% ; \mathrm{P}_{2} \mathrm{O}_{5}-10.50 \%$; $\mathrm{K}_{2} \mathrm{O}-5.30 \%$, and 2. SAPRO Elixir ${ }_{\mathrm{Ju}}\left(\mathrm{SE}_{\mathrm{Ju}}\right): \mathrm{N}_{\text {tot }}-$ $4.61 \% ; \mathrm{P}_{2} \mathrm{O}_{5}-8.38 \% ; \mathrm{K}_{2} \mathrm{O}-10.81 \%$. Both types of these fertilizers contained equal amounts of microelements $(1 \mathrm{~m} \mathrm{HCl}): \mathrm{Cu}-13 \mathrm{mg} \mathrm{l}^{-1}, \mathrm{Zn}-70.00$ $\mathrm{mg} \mathrm{l}^{-1}, \mathrm{Mn}-32.5 \mathrm{mg} \mathrm{l}^{-1}$; $\mathrm{B}-0.85 \mathrm{mg} \mathrm{l}^{-1}, \mathrm{~S}-14.0 \mathrm{mg}$ $1^{-1}$, as well as $20.7 \%$ of humic and $32.7 \%$ of fulvic acids. Organic matter was $77 \%$ and $\mathrm{pH} 6.4$.

Based on humic preparation, as a biostimulant and complex former, mineral salts of microelements and some additives, NAS INM developed liquid Ele Gum fertilizers for additional foliar fertilizing of plants, composition of which contained humic preparation 10 $\mathrm{g}^{-1}$ and respective mineral substances, e. g., Ele 
Gum-Copper contains $\mathrm{Cu}-50 \mathrm{~g} \mathrm{l}^{-1}$; Ele Gum-Zinc $\mathrm{Zn}-50 \mathrm{~g} \mathrm{l}^{-1}$, and Ele Gum-Manganese - Mn - $50 \mathrm{~g}$ $1^{-1}$.

*) The Evaluation of Sapropel from the Lake Ubogovo, Rezekne of Latvia

Influence of sapropel-containing fertilizers on development of plants

Need of plants for specific amount of nutrients depends on their physiology, heredity, and varies depending on conditions of growing [15]. This approach was taken as a base of experiment for forming substrate and solutions for studied crops as a method of increasing their productivity.

To develop it, influence of nutritional substrate SAPRO Agro in pure form $\left(\mathrm{SA}_{100 \%}\right)$ and mixed with sand (SA $1: 7$ ) on growth and development of plants was studied in climatic chamber conditions. Various types of plants with different requirements of soil environment were selected for the experiment (Table IV).

TABLE IV.

DEVELOPMENT OF AGRICULTURAL PLANTS IN CONDITIONS OF VEGETATION EXPERIMENT.

\begin{tabular}{|c|c|c|c|c|c|c|}
\hline $\begin{array}{l}\text { Dry matter } \\
\text { Yield }\end{array}$ & $\begin{array}{l}\text { Above } \\
\text { ground } \\
\text { mass }\end{array}$ & & $\begin{array}{l}\text { Under } \\
\text { ground } \\
\text { mass }\end{array}$ & $\begin{array}{l}\text { Above } \\
\text { ground } \\
\text { mass }\end{array}$ & & $\begin{array}{l}\text { Under } \\
\text { ground } \\
\text { mass }\end{array}$ \\
\hline & $\begin{array}{c}\text { g. } \\
\text { vg. }\end{array}$ & $\%$ & $\begin{array}{c}\text { g. } \\
\text { vg. }{ }^{-1}\end{array}$ & $\begin{array}{c}\text { g. } \\
\text { vg.s. }\end{array}$ & $\%$ & g.vg.s ${ }^{-1}$ \\
\hline & \multicolumn{3}{|c|}{ Festuca rubra, + F. Ovina } & \multicolumn{3}{|c|}{ / Medicago sativa } \\
\hline 1. SM & 1.95 & 100 & 1.06 & 2.83 & 100 & 1.62 \\
\hline 2. $\mathrm{SA}_{100 \%}$ & 2.26 & 116 & 1.45 & 1.28 & 45 & 1.12 \\
\hline 3. $\mathrm{SA}_{1: 7}$ & 2.45 & 126 & 1.75 & 2.94 & 104 & 1.96 \\
\hline 4. $\mathrm{SA}_{1: 7}$ & & & & & & \\
\hline $\begin{array}{l}+2 \mathrm{SE}_{\mathrm{L}} \\
\text { 5. } \mathrm{SA}_{1.7}\end{array}$ & 2.50 & 128 & 1.81 & 3.31 & 117 & 2.96 \\
\hline$+2 \mathrm{x} \mathrm{SE}_{\mathrm{Ju}}$ & 2.46 & 126 & 1.95 & 3.40 & 120 & 2.94 \\
\hline \multirow[t]{2}{*}{$\mathrm{RS}_{0.05}$} & 0.03 & & 0.02 & 0.06 & & 0.03 \\
\hline & \multicolumn{3}{|c|}{ Solanum lycopersicum } & \multicolumn{2}{|c|}{ / Lactuca sativa } & \\
\hline 1. SM & 1.69 & 100 & 1.18 & 2.20 & 100 & 1.30 \\
\hline 2. $\mathrm{SA}_{100 \%}$ & 1.72 & 102 & 1.23 & 2.42 & 110 & 1.40 \\
\hline 3. $\mathrm{SA}_{1: 7}$ & 1.73 & 102 & 1.60 & 2.56 & 116 & 1.46 \\
\hline 4. $\mathrm{SA}_{1: 7}$ & & & & & & \\
\hline $\begin{array}{l}+2 \mathrm{SE}_{\mathrm{L}} \\
\text { 5. } \mathrm{SA}_{1: 7}\end{array}$ & 1.94 & 115 & 1.83 & 2.64 & 120 & 1.96 \\
\hline$+2 x \mathrm{SE}_{\mathrm{Ju}}$ & 1.97 & 117 & 1.79 & 2.59 & 118 & 1.99 \\
\hline $\mathrm{RS}_{0.05}$ & 0.04 & & 0.03 & 0.02 & & 0.03 \\
\hline
\end{tabular}

Grasses, as the least demanding to environment reaction, grew and developed on all studied types of substrate. Increase of dry matter by 16-28 \% compared to control was observed in all versions of the experiment. Weight of overground part in the best version $4 . \mathrm{SA}_{1: 7}+2 \mathrm{xSE}_{\mathrm{L}}$ was $2.50 \mathrm{~g}$ veg.s ${ }^{-1}$ (vg.s), which is by $28 \%$ higher than that of control, weight of roots was $1.95 \mathrm{~g}$ veg. $\mathrm{s}^{-1}$

Based on results of experiment, alfalfa reacted to additional fertilizing well. Therefore, the most efficient were variants 5 . $\mathrm{SA}_{1: 7}+2 \times \mathrm{SE}_{\mathrm{L}}$ and $\mathrm{SA}_{1: 7}+$ $2 \mathrm{xSE}_{\mathrm{Ju}}$. In these variants, height of plants was $13 \mathrm{~cm}$, and dry matter of grass -3.31 to $3.40 \mathrm{~g} \mathrm{veg} \mathrm{s}^{-1}$, which was by 17 to $20 \%$ higher than that of control. Welldeveloped root system was 2.96 to $2.94 \mathrm{~g}$. In variant 2 . $\mathrm{SA}_{100 \%}$, alfalfa results were by $35 \%$ lower than those of control.

Vegetables positively reacted to differences in nutrition. Tomato overground weight increased from $1.69 \mathrm{~g}$ veg. $\mathrm{s}^{-1}$ in control to $1.97 \mathrm{~g}$ veg. $\mathrm{s}^{-1}$ in $5 . \mathrm{SA}_{1: 7}+$ $2 \mathrm{xSE}_{\mathrm{Ju}}$, which constituted increase by $17 \%$. For lettuce, the highest weight was in variant $4 . \mathrm{SA}_{1: 7}+$ $2 \mathrm{xSE}_{\mathrm{L}}(2.64 \mathrm{~g})$, which is explained by responsiveness of this plant to content of nitrogen in fertilizer, where in fertilizers $2 \mathrm{xSE}_{\mathrm{L}}$ and $2 \mathrm{xSE}_{\mathrm{Ju}}$ content of $\mathrm{N}_{\text {tot }}$ was 9.11 and $7.10 \%$ respectively. Regardless of type of plants, the best results in all factors were obtained in variants $3 . \mathrm{SA}_{1: 7} ; 4 . \mathrm{SA}_{1: 7}+2 \mathrm{xSE}_{\mathrm{L}}$ and $5 . \mathrm{SA}_{1: 7}+$ $2 \mathrm{XSE}_{\mathrm{Ju}}$, which proves efficiency of using SAPRO Agro and SAPRO Elixsir fertilizers Inhibitory action was detected in variant 2 . $\mathrm{SA}_{100 \%}$, where growth of plants were slightly delayed. This was affected by both content of iron and acidity of environment. However, after mixing with sand in proportion 1:7, overground weight of plants is increased by 2-16\% compared to that of control. Thus, in 2 . $\mathrm{SA}_{100 \%}$ this factor was: cereals -2.26 , alfalfa -1.28 , tomato 1.72 , and lettuce $-2.42 \mathrm{~g}$ veg. $\mathrm{s}^{-1}$, and in variant 3 . $\mathrm{SA}_{1: 7}-2.45,2.94,1.73,2.56 \mathrm{~g}$ veg. $\mathrm{s}^{-1}$ respectively. Correlation coefficients were determined based on the experiment data. Increase in overground weight of studied crops and content of nutrients in fertilizers are in close correlation $(\mathrm{r}=0.60-0.75)$.

Influence of studied fertilizers in field experiments on development of spring barley

Meteorological conditions in vegetation period in certain years of studies differed from average, but did not affect crop capacity of barley considerably.

After evaluating efficiency of each variant of the experiment depending on the studied factors, it was determined that variants $3.2 \mathrm{xSE}_{\mathrm{L}}$ and $4.2 \mathrm{xSE}_{\mathrm{Ju}}$ gave significant increase of grain yield $0.53-0.60 \mathrm{t} \mathrm{ha}^{-1}$, compared to that of control, which was $14-16 \%$ (Table V). Thus, yield in control was 3.68, and in variants 3 and $4-4.21$ and $4.28 \mathrm{t} \mathrm{ha}^{-1}$, respectively. In variant, where additional fertilizing was carried out by sapropel solution, grain yield increased by $9 \%$.

After additional fertilizing by SAPRO Elexsir fertilizer with different nutritional composition, quality of spring wheat grains changed. Variants with their use resulted in increased fullness of grains. Weight of 1000 grains differed in variants and was $49.2 \mathrm{~g}$ in control. The highest results were obtained in variant $4.2 \mathrm{XSE}_{\mathrm{Ju}}-54.5 \Gamma(11 \%$ of control $)$. In variant 2. SAPRO and $3.2 x E_{L}$, this result was slightly lower $-50.3(2 \%)$ and $52.0(6 \%)$, respectively. Nature of grains in additional fertilizing was 651-660 $\mathrm{g} \mathrm{l}^{-1}$, by 8-17 $\mathrm{g} \mathrm{l}^{-1}$ higher than in control. 
TABLE V

AVERAGE PRODUCTIVITY OF SPRING BARLEY IN 2 YEARS

\begin{tabular}{|c|c|c|c|c|}
\hline \multirow[b]{2}{*}{ Parameter } & \multicolumn{4}{|c|}{ Variants } \\
\hline & 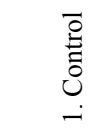 & 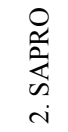 & 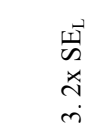 & 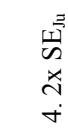 \\
\hline Yield * $\mathrm{t} \mathrm{ha}^{-1}$ & 3.68 & 4.02 & 4.21 & 4.28 \\
\hline$\%$ of control & 100 & 109 & 114 & 116 \\
\hline Plant height, cm & 60 & 64 & 66 & 68 \\
\hline $\begin{array}{l}\text { Vegetation period, } \\
\text { days }\end{array}$ & 95 & 94 & 96 & 96 \\
\hline TKW,g & 49.2 & 50.3 & 52.0 & 54.5 \\
\hline Volume weight,g 1-1 & 643 & 651 & 657 & 66.0 \\
\hline Protein $* *, \%$ & 11.9 & 12.0 & 12.3 & 12.4 \\
\hline Starch, \% & 64.2 & 62.8 & 61.6 & 55.3 \\
\hline
\end{tabular}

Protein in spring barley is the most important component, on which high quality of agricultural animal feed depends when using grains in zootechny [1]. SAPRO Elexsir favoured increase of protein content in grains, which was the highest in variant 4 . $2 \mathrm{xSE}_{\mathrm{Ju}}-12.4 \%$

Starch content varied from $55.3 \%$ in variant to $64.2 \%$ in control. Introduction of SAPRO Elexsir fertilizers decreased starch content by $8.9 \%$ compared to that of control, since protein was accumulated more actively on additionally fertilized plots. Regression connection between protein and starch contents is inverse, average, $\mathrm{r}=-0.63$

Numerous literature data show that fresh sapropel is not an effective fertilizer and requires additional processing $[2,6,18]$. Its positive effect is manifested in subsequent years of crop cultivation. In our experiments, no negative effects were observed after watering with working sapropel solution 1:20, yield increase was $9 \%$ compared to the control. Working solution on leaves and open root system additionally feeds plants and causes no negative consequences.

Influence of studied fertilizers in field conditions on development of winter wheat and maize

One of the most common and economically substantiated methods of using microfertilizers today in majority of countries is additional foliar fertilizing of crops during the periods, when their need for microelements is the highest. Important agrotechnical and ecologically neutral method in practice of plant cultivation is use of growth stimulants of humic nature, which improve life processes in plants, but are not sources of nutrients [16].

The abundance of tillable area in Republic of Belarus (NAS INM, NAS ISSA) is characterized by the content of main microelements as not sufficient enough for stable high yield of crops production.
Currently, microfertilizers for crops cultivation are only used within $30-40 \%$ of their need.

TABLE VI.

WINTER WHEAT GRAIN YIELD, IN AVERAGE FOR 2 YEARS,

\begin{tabular}{|c|c|c|c|c|c|c|}
\hline The timing & \multicolumn{2}{|c|}{ of tillering } & \multicolumn{2}{|c|}{ in the pipe } & \multicolumn{2}{|c|}{ of earing } \\
\hline Variants & 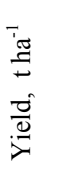 & 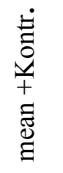 & 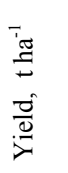 & 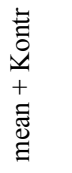 & 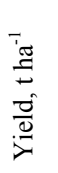 & 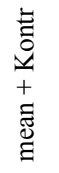 \\
\hline 1.Control & 5.90 & - & 5.90 & - & 5.90 & - \\
\hline 2.Humic preparation & 6.35 & 0.45 & 6.22 & 0.32 & 6.00 & 0.10 \\
\hline 3.EleGum-Cuprum & 6.46 & 0.56 & 6.42 & 0.52 & 6.00 & 0.10 \\
\hline $\begin{array}{l}\text { 4.EleGum- } \\
\text { Manganese }\end{array}$ & 6.56 & 0.66 & 6.35 & 0.45 & 6.07 & 0.17 \\
\hline $\begin{array}{l}\text { 5.EleGum- Cuprum } \\
\text { EleGum-Manganese }\end{array}$ & 6.78 & 0.88 & 6.69 & 0.79 & 6.14 & 0.24 \\
\hline
\end{tabular}

The most important microelements for winter wheat in conditions of sod-podzol soils are copper and manganese, for maize - zinc. As a biostimulant, humic preparation, extracted from peat during its water alkaline processing, is chosen.

Use of compositions containing, simultaneously with microelements, biologically active compounds is seen as the most efficient poly functional medium for increasing crop capacity and quality of plant products.

As seen from the data of Table VI, the most efficient is use of humic preparation and microelement fertilizers for foliar treatment of winter wheat in the period of plant tillering in spring and in stem elongation phase. Increase of grain yield after application of humic preparation only was 0.45 and $0.32 \mathrm{t} \mathrm{ha}^{-1}$, and after application of these fertilizers in tillering phase $-0.56-0.88 \mathrm{t} \mathrm{ha}^{-1}$, in stem elongation phase $-0.45-0.79 \mathrm{t} \mathrm{ha}^{-1}$. After using liquid fertilizers and humic preparation at the ear beginning, only the tendency to increase of crop capacity is retained, since obtained increase in grains of 0.1-0.24 $\mathrm{t} \mathrm{ha}^{-1}$ is statistically unreliable.

Use of humic preparation favoured increase in protein and gluten content in winter wheat grains (Table VII).

Maximum increase of protein and gluten content was obtained after treatment with humic preparation at the beginning earing, although improved quality of grains was observed even after using the preparation at earlier time. 
TABLE VII.

GRAIN QUALITY OF WINTER WHEAT

\begin{tabular}{|c|c|c|c|c|c|c|}
\hline \multirow{2}{*}{$\begin{array}{l}\text { The timing } \\
\text { Variants }\end{array}$} & \multicolumn{2}{|c|}{ of tillering } & \multicolumn{2}{|c|}{ in the pipe } & \multicolumn{2}{|c|}{ of earing } \\
\hline & 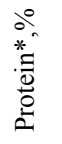 & 总 & 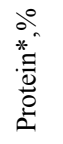 & 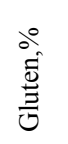 & 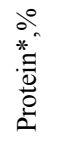 & $\begin{array}{l}\stackrel{0}{0} \\
\stackrel{\tilde{\Xi}}{\Xi} \\
0\end{array}$ \\
\hline 1.Control & 11.3 & 27.4 & 11.3 & 27.4 & 11.3 & 27.4 \\
\hline $\begin{array}{l}\text { 2.Humic } \\
\text { preparation }\end{array}$ & 11.4 & 28.8 & 11.5 & 28.0 & 12.2 & 29.6 \\
\hline $\begin{array}{l}\text { 3.EleGum- } \\
\text { Cuprum }\end{array}$ & 11.4 & 32.2 & 11.5 & 30.0 & 11.8 & 35.6 \\
\hline $\begin{array}{l}\text { 4.EleGum- } \\
\text { Manganese }\end{array}$ & 11.8 & 28.5 & 11.5 & 28.2 & 11.8 & 29.7 \\
\hline $\begin{array}{l}\text { 5.EleGum- } \\
\text { Cuprum } \\
\text { EleGum- } \\
\text { Manganese }\end{array}$ & 11.9 & 32.9 & 11.8 & 33.7 & 12.1 & 33.8 \\
\hline
\end{tabular}

Additional foliar spraying wheat plants by liquid humic fertilizers with microelements in the experiment variants favoured increase in content of protein from 0.5 to $0.8 \%$, gluten which is the main component of protein - from 2.4 to $4.2 \%$. In our experiments, the highest its level was reached in variant 3 . EleGum-Cu $-35.6 \%$, after treatment in the ear beginning phase. Amount of gluten defines quality of flour and baked bread. Stability of shape, volume and porosity of bread also depends on it. In average, by the time of fertilizer application, protein and gluten content in grains increased more at the beginning of ear. Therefore, treatment of plants in this period of growth is quite reasonable. In optimal conditions of plant nutrition, correlation between output of raw gluten and content of protein may reach the best result $-2.5 \%$. Additionally, significant increases the glutenforming ability of protein complex (weight fraction). In terms of quantity this ability may be characterized by relation of gluten content to protein content in nonmetric units. In results of the studies, gluten-forming ability of protein complex varied from 2.42 in reference variant to 2.79 in variant 5 .

TABLE VIII.

EFFECT OF ELEGUM HUMIC MICROELEMENT FERTILIZERS ON AVERAGE MAIZE GREEN MASS YIELD

\begin{tabular}{lccc}
\hline \multicolumn{1}{c}{ Variants } & $\begin{array}{l}\text { Yield } \\
\text { tha }^{1}\end{array}$ & $\begin{array}{l}\text { mean+ } \\
\text { kontr. }\end{array}$ & $\begin{array}{l}\mathrm{NO}_{3} \\
\mathrm{mg} \mathrm{kg}^{-1}\end{array}$ \\
\hline 1. Manure & 56.5 & - & $168-355$ \\
2. EleGum-Zinc & 65.0 & 8.5 & $89-305$ \\
3. EleGum-Cuprum & 59.0 & 2.5 & $120-308$ \\
4. EleGum-Manganese & 59.2 & 2.7 & $310-390$ \\
\hline \multicolumn{1}{c}{$* \mathrm{RS}_{0.05}=1.45$} & & &
\end{tabular}

Results of studies showed that additional foliar fertilizing of maize by EleGum-Zn, EleGum-Cu and EleGum-Mn fertilizers favoured increase in capacity of green mass and grain of corn (Table VIII and IX).
In background variant, average capacity of green mass and grain of maize in two years of studies was 56.5 and $9.98 \mathrm{t} \mathrm{ha}^{-1}$, respectively.

After using studied fertilizers, capacity of green mass increased by $2.5-8.5 \mathrm{t} \mathrm{ha}^{-1}$, and capacity of grain - by 1.00-2.06 $\mathrm{t} \mathrm{ha}^{-1}$ (Table IX). After using EleGum-Zn, EleGum-Cu and EleGum-Mn fertilizers during maize cultivation, content of nitrates in green mass did not exceed the established maximum concentration.

TABLE IX

EFFECT OF ELEGUM HUMIC MICROELEMENT FERTILIZERS ON AVERAGE MAIZE GRAIN YIELD

\begin{tabular}{lll}
\hline \multicolumn{1}{c}{ Variants } & Yield $* \mathrm{tha}^{-1}$ & mean + St \\
\hline 1. Manure & 9.98 & - \\
2. EleGum-Zinc & 12.04 & 2.06 \\
3. EleGum-Cuprum & 10.98 & 1.00 \\
4. EleGum - Manganese & 11.06 & 0.08 \\
\hline \multicolumn{2}{c}{$* \mathrm{RS}_{0.05}=0.83$} &
\end{tabular}

Application of EleGum-Zn, EleGum-Cu, EleGumMn fertilizers as additional foliar spray fertilizing maize crop provided increase for microelements content in green mass and grain at levels of: $\mathrm{Cu}-2.8$ 4.1 and $1.3-1.5 \mathrm{mg} \mathrm{kg}^{-1} ; \mathrm{Zn}-13.0-15.3$ and $14.2-16.7$ $\mathrm{mg} \mathrm{kg}{ }^{-1} ; \mathrm{Mn}-23.0-28.1$ and 2.1-4.0 mg kg-1, respectively.

\section{CONCLUSION}

Extremely rich and varied composition of organic and mineral substances of peat and sapropel allows using these natural materials as the base in creation of new types of solid and liquid organic and organicmineral fertilizers and preparations for crop cultivation.

Use of SAPROAgro and SAPROElixir fertilizer increases productivity of agricultural plants by 9$16 \%$. Sapropel in composition of fertilizers participates as physiologically active binder of the base having high ion exchange and sorption properties. It is also an additional supplier of humic substances, amino acids, including aspartic, glutamic, as well as glycine, alanine and histidine, into nutrient medium of plants.

Obtained data show efficient use of humic preparation and highly concentrated liquid EleGum fertilizers with microelements developed on its base on sandy-loam sod-podzol soils. Use of compositions containing, simultaneously with microelements, biologically active compounds is seen as the most efficient poly functional medium for increasing crop capacity and quality of plant cultivation products, provides for obtaining increase in winter wheat grains to $0.88 \mathrm{t} /$ ha, green mass of maize to $5 \mathrm{tha}^{-1}$ and grains of corn to $2.06 \mathrm{t} \mathrm{ha}^{-1}$. 


\section{REFERENCES}

[1] L. Agafonova, A. Jansons and S. Rancāne Pākšaugu un labību mistru agrofitocenozes izveidošana apstākḷos biologiiskās lauksaimniecības 10th International Scientific and Practical Conference "Environment. Technology. Resources." 2009, pp.107-112.

[2] E Baksene, A. Burba and D. Daugvilene Sapropel - organic fertilizer for improving properties of poor soils. Materials of Intern. Scien. Conf. Problems of Nature Management: Resume and Prospect (rus.), Minsk, 2012, pp.12-14.

[3] B. Dospehov Field Experiment Methodology (rus.). M. Agropromizdat, 1985,p. 283.

[4] M. Dumas, M. Dudins, K. Kaulins and S. Sapropel, humin acids and their influence on increasing of the crop capacity Latvijas Lauksaimniecības universitātes raksti J.V227 1993, pp. 68-71.

[5] A. Yermakova Methods of Biochemical Study of Plants (rus.) M.: Kolos, 1970, p.196

[6] E. Grela and K. Pietrzak Production Technology, Chemical Composition and Use of Alfalfa Protein-Xanthophyl Concentrate as Dietary Supplement. J Food Process Technol . 1.373. 2014, pp.123-128.

[7] T. Kashinskaya, A. Gavrilchik, G. Sokolov and S. "Liquid Complex Humic Microfertilizer (versions)", Resp. Belarus Patent 16753, February 28, 2013.

[8] S. Kovrik., N. Bambalov, G. Sokolov "Method for Obtaining a Complex Copper-Zinc Humic Fertilizer", Resp. Belarus Patent 16752, February 28, 2013.

[9] S. Kovrik, N. Bambalov, G. Sokolov and S. Activation of Sapropel and Peat for Obtaining New Types of Fertilizers. $2^{\text {nd }}$
Belarusian-Latvian Forum "Science, Innovations, Investments", (rus.), Minsk, 2014, pp. 19-21.

[10] B. Yagodin Agrochemistry. (rus.), M.: Kolos, 1989.

[11] Kiecolt-Glaser J. K. et al. Omega-3 supplementation lowers inflammation in healthy supplementation lowers inflammation in healthy middle- aged and older adults: A randomized controlled trial. Brain, Behavior, and Immunity, 26 (6), 2012, pp.988-982.

[12] V. Polevoy Physiology of Plants (rus.). M.: Higher school, 1989, p 167.

[13] The Report Laboratory of Animal Biochemistry and Phisiology of the Institute Biology of Latvian University. The Evaluation of Sapropel from the Lakje Ubogova.Salaspils. 2014, p. 6.

[14] M. Rak, V. Lapa, G. Sokolov.A. and S. Use of Complex Humic Microfertilezers "EleGum": Recommendations In-t on Nature Management, In-t of Soil Sciences and Agrochemistry of NAS of Belarus. (rus.), Minsk, 2013, p. 28.

[15] V. Rakovich, N. Bambalov, O. Gaydukevich and S. Complex Use of Peat and Sapropel in Belarus.. Theoretical and Practical Conf. Problems of Studying and Using Peat Resources. Tomsk. 2014, pp. 37-40.

[16] G. Sokolov, O. Krasnoberskaya, I. Simakina and S. "Scientific Basis of Using Peat, Sapropel and Products of Their Processing in Agriculture", Prirodopolzovaniye. Issue 22, 2012, pp. 67-81

[17] G. Sokolov, L. Szajdak, I. Simakina "Changes in the structure of nitrogen-containing compounds of peat-, sapropel-, and brown coal-based organic fertilizers", Agronomy Research J., 6(1), 2008, pp 149-160.

[18] J. Vigovskis Organisko mēslu un devu ietekme uz laukaugu razū un organiskās vielas saturu velēnu podzolētajās augsnes. Autoreferāts. Skrīveri. 1993, p. 65 